\title{
Video Analysis of Sensory-Motor Features in Infants with Fragile $X$ Syndrome at 9-12 Months of Age
}

\author{
Grace T. Baranek · Cassandra D. Danko • \\ Martie L. Skinner • Donald B. Bailey Jr. • \\ Deborah D. Hatton · Jane E. Roberts • \\ Penny L. Mirrett
}

Published online: 8 December 2006

(C) Springer Science+Business Media, LLC 2006

\section{Erratum to: J Autism Dev Disord \\ DOI 10.1007/s10803-005-0008-7}

The name of the fourth coauthor of this article is

Donald B. Bailey Jr. (not Donald B. Jr.)

The online version of the original article can be found at http://dx.doi.org/10.1007/s10803-005-0008-7

G. T. Baranek ( $₫)$. C. D. Danko - M. L. Skinner .

D. B. Bailey Jr. · D. D. Hatton · J. E. Roberts ·

P. L. Mirrett

Division of Occupational Science, Department of Allied Health Sciences, University of North Carolina at Chapel Hill, CB\#7120 UNC-CH, Chapel Hill, NC 27599-7120, USA

e-mail: gbaranek@med.unc.edu 